\title{
PRAWO WŁASNOŚCI ODPADÓW KOMUNALNYCH
}

\section{WPROWADZENIE}

Media, informując o planowanych, a następnie wprowadzonych, zmianach $\mathrm{w}$ systemie gospodarowania odpadami, spopularyzowały stwierdzenie, że gminy przejmą własność odpadów komunalnych. Hasło to, powtarzane wielokrotnie, utrwaliło się w świadomości społecznej. Trafiło nawet do języka prawniczego jako swoisty skrót myślowy. Warto zatem podjąć refleksję nad jego sensem i prawdziwością. Celem niniejszego artykułu jest przedstawienie wniosków z analizy tytułu prawnego do śmieci, jaki przysługuje poszczególnym podmiotom prawnym zaangażowanym w proces gospodarowania odpadami od ich powstania do utylizacji.

Rozważania na ten temat z pozoru wydają się pobawione jakiejkolwiek doniosłości w sferze prawnej czy ekonomicznej. W istocie wnioski z nich płynące maja praktyczne znaczenie, choćby w kontekście kradzieży odpadów. Warto pamiętać, że w tle owych rozważań znajduje się proces gospodarowania odpadami będący wyzwaniem dla współczesnego świata i jednocześnie dochodowa gałęzia gospodarki. O wielkich pieniądzach, jakie wchodzą w grę, można mówić w kontekście zarówno rynku usług wywozu i zagospodarowywania odpadów komunalnych, jak i zysków z odzysku surowców wtórnych. Dość powiedzieć, że przygotowany przez Bank of America Merrill Lynch w kwietniu 2013 r. raport „No time to waste - global waste primer” szacuje wartość światowego rynku odpadów komunalnych na kwotę ok. 410-430 mld USD, a rozumianej szeroko branży śmieciowej (w tym odpady radioaktywne, medyczne czy spalarnie śmieci) - na bilion dolarów ${ }^{1}$.

\section{ODPAD JAKO PRZEDMIOT STOSUNKU CYWILNOPRAWNEGO}

Obiekty zwane $\mathrm{w}$ języku powszechnym śmieciami polski ustawodawca określa najczęściej mianem „odpadów”. Zgodnie z ustawą z 14 grudnia 2012 r. o odpadach ${ }^{2}$ - przez pojęcie odpadów rozumie się każdą substancję lub przedmiot, których posiadacz pozbywa się, zamierza się pozbyć lub do których po-

${ }^{1}$ Raport dostępny na: http://www.longfinance.net/images/reports/pdf/baml_waste_2013.pdf.

2 Dz. U. 2013, poz. 21 (dalej jako: UO). 
zbycia się jest obowiązany (art. 3 ust. 1 pkt 6). Mianem odpadów komunalnych określa się zaś „odpady powstające w gospodarstwach domowych, z wyłączeniem pojazdów wycofanych z eksploatacji, a także odpady niezawierające odpadów niebezpiecznych pochodzące od innych wytwórców odpadów, które ze względu na swój charakter lub skład sa podobne do odpadów powstających w gospodarstwach domowych; zmieszane odpady komunalne pozostaja zmieszanymi odpadami komunalnymi, nawet jeżeli zostały poddane czynności przetwarzania odpadów, która nie zmieniła w sposób znaczący ich właściwości" (art. 3 ust. 1 pkt 7 UO).

Przytoczone wyżej definicje legalne stanowią niewielka pomoc przy kwalifikowaniu odpadów do określonej klasy przedmiotów wyróżnianych w polskim systemie prawnym. Definicji odpadów można ponadto zarzucić pewną nieporadność językowa. Otóż, pierwszy człon wyrażenia definiującego (definiensa) zawiera zwrot „każda substancja lub przedmiot”. Stawianie w ramach alternatywy łącznej wyrażenia „substancja” oraz „przedmiot” nie ma sensu z punktu widzenia języka naturalnego oraz logiki³ .

Niezależnie od powyższego ustawodawca wskazuje, że odpady moga stanowić przedmiot posiadania ${ }^{4}$. Stwierdzenie to pośrednio wskazuje, że odpady z punktu widzenia polskiego systemu prawnego zakwalifikować należy do kategorii rzeczy. Ustawodawca wyraźnie wskazał, że przedmiotem posiadania może być wyłącznie rzecz ${ }^{5}$. Wynika to z treści art. 336 k.c. ${ }^{6}$ Dopuszczalne wydaje się posiadanie części składowej rzeczy (ruchomej bądź nieruchomości), o ile możliwe jest zapewnienie sprawowania władztwa nad taką rzeczą ${ }^{7}$.

${ }^{3}$ Oba pojęcia sa wieloznaczne, mają różne znaczenia w zależności od kontekstu bądź dziedziny naukowej, w której języku są używane. Podstawowe znaczenie słowa „przedmiot” w języku potocznym to realny, fizyczny element otaczającego świata (E. Sobol [red.], Maty stownik języka polskiego, Warszawa 1994, s. 720). Pojęcie „substancja” jest zaś definiowane przede wszystkim jako ,jednorodny rodzaj materii o określonym składzie chemicznym” (E. Sobol [red.], op. cit., s. 892) bądź „rzecz, przedmiot, obiekt materialny” (Encyklopedia popularna PWN, Warszawa 1982, s. 747). W języku naturalnym są to wyrażenia bliskoznaczne.

${ }^{4} \mathrm{~W}$ samej definicji odpadów mowa jest o posiadaczu odpadów, pojęcie to jest również zdefiniowane w art. 3 ust. 1 pkt 19 UO.

${ }^{5}$ Jest to tradycyjne rozwiązanie wywodzące się z prawa rzymskiego, które dopuszczało możliwość posiadania wyłącznie rzeczy. Pod rządami regulacji poprzedzających obecnie obowiązujacy Kodeks cywilny, tj. dekretu z 11 października 1946 r. - Prawo rzeczowe, sytuacja była nieco bardziej skomplikowana. Zgodnie z art. $296 \S 1$ Prawa rzeczowego uznano, że posiadaniem jest wykonywanie wyłącznie takich praw, z którymi łączy się władza nad rzeczą. Przepis art. $296 \S 2$ Prawa rzeczowego stanowił: ,kto rzeczą faktycznie włada w zakresie, odpowiadającym treści użytkowania, służebności, zastawu, prawa najmu lub dzierżawy albo innego prawa, z którym łączy się władza nad rzecza, jest posiadaczem prawa, którego treści jego władza faktyczna odpowiada”. Dlatego zrodziła się wątpliwość, czy przedmiotem posiadania może być jedynie rzecz, czy również prawo, którego treścią jest władztwo nad rzecza.

${ }^{6}$ Kodeks cywilny w art. 336 stanowi, że „posiadaczem rzeczy jest zarówno ten, kto nią faktycznie włada jak właściciel (posiadacz samoistny), jak i ten, kto nią faktycznie włada jak użytkownik, zastawnik, najemca, dzierżawca lub mający inne prawo, z którym łączy się określone władztwo nad cudzą rzeczą (posiadacz zależny)".

7 Tak A. Kunicki, w: System prawa cywilnego, red. W. Czachórski, t. 2: Wtasność i inne prawa rzeczowe, red. J. Ignatowicz, Wrocław-Warszawa-Kraków-Gdańsk 1977, s. 852; J. Gołaczyński, w: System prawa prywatnego, t. 2: Prawo cywilne - część ogólna, red. Z. Radwański, Warszawa 2002, s. 100; postanowienie SN z 6 czerwca 1973 r., I CR 413/73, Lex, nr 7265 oraz postanowienie SN z 19 stycznia 1988 r., III CRN 459/87, Lex, nr 8858. 
Powyższego wniosku nie neguje treść art. $352 \S 1$ k.c.: „kto faktycznie korzysta z cudzej nieruchomości w zakresie odpowiadającym treści służebności, jest posiadaczem służebności”. Pojęcie posiadania służebności można zakwalifikować jako pewien skrót myślowy. Nie powinien on być rozumiany jako dopuszczalność ustanowienia posiadania na prawie służebności nieruchomości. Należy zgodzić się z opinią doktryny, że z przepisu tego wynika raczej, że przedmiotem posiadania jest nieruchomość, lecz w zakresie wyznaczonym treścią służebności ${ }^{8}$.

Abstrahując od definicji legalnej odpadów, kwalifikacja odpadów do kategorii rzeczy, a ściślej - rzeczy ruchomych, jest zgodna z powszechną intuicja prawna w tym zakresie. Rzeczami w rozumieniu polskiego ustawodawstwa (art. 45 k.c.) są części przyrody, występujące w stanie pierwotnym bądź przetworzonym - niezależnie od tego, czy prezentują jakąkolwiek wartość majątkową ${ }^{9}$. Odpady niewątpliwie są wyodrębnionymi z przyrody przedmiotami materialnymi. Zważywszy, że ustawodawca wprost stanowi, że odpady moga podlegać obrotowi ${ }^{10}$, nie można mówić w tym przypadku o przedmiotach wyłączonych z obrotu (nie stanowią res extra commercium). Jednocześnie art. 2 UO stanowi, że jej przepisów nie stosuje się m.in. do: gazów i pyłów wprowadzanych do atmosfery bądź ścieków, tj. obiektów materialnych, które nie będąc w postaci wyodrębnionej, nie są traktowane jako rzeczy ${ }^{11}$.

\section{MOMENT POWSTANIA ODPADU}

Cytowana wyżej definicja odpadów wskazuje, w którym momencie rzecz, względnie jej część składowa, staje się odpadem. Otóż decydująca jest chwila, w której posiadacz owej rzeczy:

1) zamierza się jej pozbyć lub

2) pozbywa się jej, lub

3) prawnie zobowiązany jest do jej pozbycia się.

Każdy z wymienionych wyżej przypadków wymaga odrębnego omówienia:

1. Samo powzięcie zamiaru pozbycia się określonej rzeczy może spowodować, że rzecz ta staje się odpadem. Powzięcie zamiaru pozbycia się rzeczy można zakwalifikować zatem jako doniosły prawnie stan psychiczny, będący częścią składową stanu faktycznego ${ }^{12}$ opisywanego w hipotezie normy prawnej. W doktrynie powszechnie przyjmuje się, że określone stany psychiczne

8 J. Gołaczyński, w: System prawa prywatnego, t. 2, s. 82.

${ }^{9}$ Z. Radwański, Prawo cywilne - część ogólna, Warszawa 2005, s. 117.

${ }^{10} \mathrm{~W}$ art. 3 ust. 1 pkt 20 UO definiuje się pośrednika w obrocie odpadami, a w art. 3 ust. 1 pkt 27 UO - sprzedawcę odpadów.

${ }^{11}$ Z. Radwański, Prawo cywilne - część ogólna, Warszawa 2005, s. 127.

12 A. Wolter, J. Ignatowicz, K. Stefaniuk, Prawo cywilne, Warszawa 2000, s. 115, definiuja stan faktyczny jako zjawisko złożone, obejmujące poza zdarzeniami prawnymi, niebędące zdarzeniami stany prawne, a niekiedy także i stany psychiczne. 
(np. dobra wiara, wina, brak świadomości lub swobody, błąd, obawa wywołana groźba) moga być elementem korygujacym skutki zdarzenia prawnego ${ }^{13}$, rozumianego jako zdarzenie obiektywnego świata zewnętrznego, tj. fakt, z którym hipotezy norm wiążą konsekwencje cywilnoprawne określone w ich dyspozycjach $^{14}$. Wprowadzenie do stanu faktycznego elementów subiektywnych może prowadzić do powstania innych skutków prawnych zdarzenia prawnego niż te, które miałyby wystapić na podstawie nieskorygowanego stanu faktycznego ${ }^{15}$. Jako przykład podać można sytuację, gdy osoba, której użyczono dana rzecz, poweźmie zamiar jej przywłaszczenia. Z tym momentem rodzi się odpowiedzialność deliktowa takiej osoby. Zatem sam zamiar przywłaszczenia rzeczy spowodował powstanie obowiązku odszkodowawczego z tytułu popełnionego deliktu.

W rozważanym przypadku zamiar pozbycia się rzeczy powoduje jej zakwalifikowanie prawne jako odpadu. Posiadacz rzeczy staje się posiadaczem odpadu, ze wszystkimi tego prawnymi konsekwencjami.

2. Ustawodawca przesądził, że odpadem jest również rzecz, której posiadacz „pozbywa się”.

Co należy rozumieć przez pojęcie „pozbycia się”? Według słownika języka polskiego pozbyć się znaczy tyle, co odsunaćc coś od siebie, uwolnić się od czegoś ${ }^{16}$. Z prawnego punktu widzenia pozbycie się rzeczy oznacza wyzbycie się jej posiadania. O tym, czy jest to wyzbycie się posiadania zawsze w sposób umożliwiajacy zawładnięcie nią każdemu, czy możliwe jest pozbycie się rzeczy na rzecz konkretnej osoby, mowa będzie w punkcie VI.

Za istotny należy uznać fakt, że w definicji odpadów w kontekście pozbycia się rzeczy użyto czasownika w trybie niedokonanym. Oznacza to, że dla zakwalifikowania rzeczy jako odpadu wystarczajace jest zainicjowanie przez posiadacza czynności zmierzających do pozbycia się odpadu. Rozróżnienie to niemal nie ma znaczenia w przypadku wyrzucenia butelki po napoju do kosza w parku, gdyż wówczas jest to pojedyncza czynność, której efektem jest pozbycie się rzeczy. Większej wagi nabiera ono w przypadku odpadów gromadzonych przez ich posiadaczy celem przekazania podmiotowi zobowiązanemu do ich odbioru. W takiej sytuacji pomiędzy przeznaczeniem rzeczy do pozbycia się jej a momentem definitywnego pozbycia się odpadu może upłynąć nawet kilka tygodni lub dłuższy okres. W owym okresie przejściowym rzecz z punktu widzenia prawa jest już odpadem, ale posiadaczem odpadu nadal pozostaje osoba pozbywająca się go. Przepis art. 3 ust. 1 pkt 19 UO definiuje posiadacza odpadów jako wytwórcę odpadów lub osobę fizyczna, osobę prawną oraz jednostkę organizacyjną nieposiadającą osobowości prawnej będące w posia-

${ }^{13}$ Tak Z. Banaszczyk, w: System prawa prywatnego, t. 1: Prawo cywilne - część ogólna, red. M. Safjan, Warszawa 2007, s. 879.

14 Tak Z. Radwański, Prawo cywilne-część ogólna, s. 214-215.

15 S. Grzybowski, System prawa cywilnego, red. W. Czachórski, t. 1: Część ogólna, red. S. Grzybowski, Wrocław-Warszawa-Kraków-Gdańsk-Łódź 1985, s. 191.

16 E. Sobol (red.), op. cit., s. 693. 
daniu odpadów. Cytowany przepis konstruuje domniemanie prawne, że „władający powierzchnią ziemi” ${ }^{17}$ jest posiadaczem odpadów znajdujących się na nieruchomości.

3. Trzecim elementem, który decyduje o tym, że rzecz staje się odpadem $\mathrm{w}$ rozumieniu ustawy, jest istnienie prawnego obowiązku pozbycia się jej.

Przykładu odpadu z tej kategorii dostarczaja postanowienia ustawy z 20 stycznia 2005 r. o recyklingu pojazdów wycofanych z eksploatacji (Dz. U. 2005, Nr 25, poz. 202). Przepis art. 18 ustawy nakazuje właścicielowi pojazdu wycofanego z eksploatacji (pojazd, który nie spełnia wymagań technicznych, zapewniających ochronę środowiska lub zdrowia, lub życia ludzi) przekazanie go przedsiębiorcy prowadzącemu stację demontażu lub przedsiębiorcy prowadzącemu punkt zbierania pojazdów. Zatem wycofanie pojazdu z eksploatacji oznacza obowiązek jego recyklingu, a tym samym powoduje, że pojazd staje się odpadem.

\section{PRAWA GMINY DO ODPADU}

Wbrew informacjom prasowym treść znowelizowanej ustawy z 13 września 1996 r. o utrzymaniu czystości i porządku w gminach ${ }^{18} \mathrm{w}$ żaden sposób nie wskazuje, jakoby gmina stała się automatycznie, ex lege właścicielem odpadów komunalnych wytwarzanych na jej obszarze. Zmiany dokonane w systemie gospodarowania odpadami komunalnymi polegają przede wszystkim na obligatoryjnym nałożeniu na gminy obowiązku zorganizowania odbierania odpadów komunalnych od właścicieli nieruchomości, na których zamieszkują mieszkańcy (art. 6c ust. 1 UPCG) ${ }^{19}$. Przyjęcie tego obowiązku przez gminę nie wiąże się jednak z przejmowaniem ex lege władztwa nad odpadami w charakterze posiadacza samoistnego. W szczególnym przypadku gmina może stać się właścicielem odpadów, ale: 1) będzie to wynikało z jej statusu jako podmiotu odpowiedzialnego w danej sytuacji za zagospodarowywanie od-

\footnotetext{
17 Wyrażenie ustawowe oznacza osobę, która użytkuje nieruchomość gruntową na podstawie jakiegokolwiek tytułu prawnego (prawo własności, dzierżawa, najem etc.) lub nawet bez takiego tytułu.

18 T.jedn.: Dz. U. 2012, Nr 391 (dalej jako: UPCG).

${ }^{19}$ W uzasadnieniu projektu ustawy z 1 lipca 2011 r. o zmianie ustawy o utrzymaniu czystości i porządku w gminach oraz niektórych innych ustaw (nr druku sejmowego: 3670) mowa jest o „przejęciu przez gminy obowiązków właścicieli nieruchomości w zakresie zagospodarowania odpadów komunalnych". Przytoczone zdanie może budzić kontrowersje odnośnie do tego, czy obowiązek taki ciążył na właścicielach nieruchomości przed wejściem w życie nowelizacji. Spór może dotyczyć niejednoznacznego na gruncie przepisów UPCG znaczenie terminu „zagospodarowanie odpadów” (o czym niżej). Interpretacja brzmienia art. 6a ust. 1 UPCG przed nowelizacją i po niej w kontekście dodanego rozdziału 3a wskazuje, że niewątpliwie nastapiło przejęcie przez gminy obowiązków w zakresie pozbywania się zebranych na terenie nieruchomości odpadów komunalnych w sposób zgodny z przepisami ustawy i przepisami odrębnymi, o którym to sposobie mowa w art. 5 ust. 1 pkt 3b) UPCG.
} 
padów ${ }^{20} ; 2$ ) nastapi to $\mathrm{w}$ związku $\mathrm{z}$ faktem odebrania odpadów od właściciela nieruchomości, a nie z samym ich wytworzeniem na terenie gminy.

Poniższy wywód wyjaśnia, że o nabyciu własności odpadów można mówić w przypadku podmiotów, które są odpowiedzialne za zagospodarowywanie odpadów. Chodzi tutaj jednak o szczególne rozumienie odpowiedzialności za zagospodarowywanie odpadów, które ściśle łączy się z interpretacją pojęcia „zagospodarowywanie odpadów” w świetle art. 6d ust. 1 UPCG. Zgodnie $\mathrm{z}$ art. $6 \mathrm{~d}$ ust. 1 UPCG wójt, burmistrz lub prezydent miasta jest obowiąany zorganizować przetarg: 1) na odbieranie odpadów komunalnych od właścicieli nieruchomości, o których mowa w art. 6c, 2) albo przetarg na odbieranie i zagospodarowanie tych odpadów. Nieco upraszczając, można stwierdzić, że w pierwszym przypadku podmiotem odpowiedzialnym za zagospodarowanie odpadów komunalnych jest gmina, w drugim zaś - odpowiedzialność tę przejmuje podmiot wyłoniony w ramach przetargu. Mowa jest tutaj o odpowiedzialności, która ciąży na danym podmiocie niezależnie od tego, czy prowadzi on jednocześnie RIPOK, czy nie. Gmina albo podmiot wyłoniony w drodze przetargu na odbieranie i zagospodarowanie odpadów bierze na siebie zobowiązanie do doprowadzenia do sytuacji, w której odbierane odpady zostają zagospodarowane $^{21} \mathrm{w}$ sposób zgodny z obowiązującymi przepisami prawa. Moga oczywiście w tym zakresie posługiwać się podmiotem prowadzącym RIPOK. Nie ogranicza to jednak ich odpowiedzialności w tym zakresie.

Ustanowiona $\mathrm{w}$ wyniku nowelizacji norma prawna wyrażona $\mathrm{w}$ art. $6 \mathrm{c}$ ust. 1 UPCG, który stanowi, że gminy są obowiązane do zorganizowania odbierania odpadów komunalnych od właścicieli nieruchomości, na których zamieszkują mieszkańcy, sama w sobie nie wprowadza jakichkolwiek zmian w sferze własności wytwarzanych odpadów. Sposób zorganizowania przez gminę gospodarowania odpadami, w granicach przewidzianych w rozdziale 3a UPCG (,Gospodarowanie odpadami komunalnymi przez gminę"), może skutkować tym, że inny niż gmina podmiot będzie nabywał własność odpadów komunalnych.

\section{PIERWOTNY WŁAŚCICIEL ODPADU}

Przepisy UO oraz UPCG kieruja przewidziane w nich obowiązki do adresatów określonych inaczej niż jako właściciele odpadów. Ustawa o odpadach posługuje się pojęciem „posiadacz odpadów”, którego czyni adresatem więk-

${ }^{20} \mathrm{~W}$ dalszym toku wywodów wyjaśnione zostanie, o jakiego rodzaju odpowiedzialność tu chodzi.

${ }^{21}$ Wobec braku ustawowej definicji pojęcia „zagospodarowanie odpadu” (ustawodawca definiuje jedynie termin „gospodarowanie odpadami”) istnieją wątpliwości, co do precyzyjnego znaczenia, jakie ustawodawca nadaje temu pojęciu na gruncie poszczególnych przepisów UPCG. Szczegółowe rozważania na ten temat wykraczają poza ramy niniejszego artykułu, stąd z konieczności należy ograniczyć się do stwierdzenia, że w kontekście art. 6d ust.1 UPCG nie chodzi o faktyczne wykonywanie określonych czynności, których przedmiotem są odpady (np. unieszkodliwianie czy odzysk). Nie chodzi również o generalną odpowiedzialność gminy za zorganizowanie procesu gospodarowania odpadami na jej terenie, jaka spoczywa na gminie na podstawie przepisów UPCG. Należy przyjąć, że pojęcie to jest w tym przepisie użyte w kontekście obowiązku zdefiniowania $\mathrm{w}$ ofercie przetargowej sposobu postępowania z odpadami oraz obowiązku zadbania, aby założenia te były realizowane zgodnie $\mathrm{z}$ wymogami prawa. 
szości obowiązków związanych z gospodarką odpadami. UPCG nakłada z kolei obowiązki na „właścicieli nieruchomości”. Zgodnie z definicją legalną zawarta w art. 2 ust. 1 pkt 4 UO pojęcie „właściciele nieruchomości” należy rozumieć szerzej, zaliczając do tej kategorii również „współwłaścicieli, użytkowników wieczystych oraz jednostki organizacyjne i osoby posiadające nieruchomości w zarządzie lub użytkowaniu, a także inne podmioty władające nieruchomością". W świetle przepisów UO obie kategorie podmiotów łączy wspomniane wyżej domniemanie prawne, że władający powierzchnią ziemi jest posiadaczem odpadów znajdujących się na nieruchomości (art. 3 ust. 1 pkt 19).

Obie wymienione ustawy nie regulują w żaden sposób zagadnienia własności odpadów. W szczególności nie przesądzaja, kto jest właścicielem odpadów od momentu ich wytworzenia, jak również, czy - a jeżeli tak, to w jaki sposób prawo własności przechodzi z jednego podmiotu na drugi. Podobnie, używając pojęcia posiadacza odpadów, przepisy UO nie rozróżniają posiadania samoistnego i zależnego. Przewidziane w art. 3 ust. 1 pkt 19 UO domniemanie prawne, że władający powierzchnią ziemi jest posiadaczem odpadów znajdujących się na nieruchomości, nie wskazuje, o jaki rodzaj posiadania chodzi ${ }^{22}$. Sytuacja ta jest zapewne rezultatem tego, że ustawodawca odróżnia sferę własności odpadów (zagadnienie cywilistyczne) od kwestii administracyjnych obowiązków związanych z gospodarką odpadami. Wbrew cywilistycznej intuicji, która podpowiada, że osobą odpowiedzialna za rzecz jest jej właściciel, odpowiedzialność za odpad może kształtować się zupełnie inaczej w świetle prawa administracyjnego. Związane jest to z charakterem odpadu jako obiektu - co do zasady niepotrzebnego, uciążliwego, którego należy się pozbyć. Cecha ta pozostaje w sprzeczności ze standardowym pojmowaniem przedmiotu własności jako materialnego składnika majątkowego, nośnika określonej wartości.

W przypadku nowo wytworzonych odpadów czynnikami decydującymi o tym, kto jest ich pierwotnym właścicielem, są najczęściej:

- stosunek prawny, w ramach którego odpad powstał,

- osoba właściciela rzeczy, z której odpad ten powstał,

- osoba wytwórcy odpadu.

Właścicielem nowo powstałego odpadu jest w zdecydowanej większości przypadków właściciel rzeczy, z której odpad ten powstał. Taka prawidłowość zachodzi, jeżeli odpad nie został wytworzony jako produkt uboczny w ramach umownego stosunku prawnego (np. umowa o dzieło, zlecenie itp.). Strony umowy mogą dowolnie ukształtować kwestię własności odpadów powstających w związku z realizacją umowy (np. wykonania mebla na zamówienie, usług budowlanych, remontowych itp.). W praktyce rzadko w tego rodzaju umowach reguluje się wprost kwestię własności odpadów. Zwykle umowy zawierają postanowienia na temat obowiązków stron odnośnie do utrzymania porządku w miejscu ich wykonywania, w tym obowiązków dotyczących zagospodarowania powstałych odpadów.

${ }^{22}$ Inaczej niż w przypadku domniemania prawnego wyrażonego w art. 339 k.c., który wyraźnie stanowi, że chodzi o posiadanie samoistne (,Domniemywa się, że ten, kto rzeczą faktycznie włada, jest posiadaczem samoistnym"). 
Podstawy prawnej opisanych wyżej wniosków można upatrywać w stosowanym odpowiednio art. 192 k.c. przez odwołanie się do analogii pomiędzy przetworzeniem rzeczy w rozumieniu art. 192 k.c. a wytworzeniem odpadu. Przywołany przepis stanowi, że właścicielem nowej rzeczy ruchomej wytworzonej z cudzych materiałów jest jej wytwórca tylko wówczas, gdy wartość nakładu pracy jest większa od wartości materiałów, a przetworzenie nastąpiło w dobrej wierze. W pozostałych przypadkach rzecz wytworzona staje się własnością właściciela materiałów. Reguła ta dotyczy zarówno sytuacji, gdy przetworzenie, o którym mowa w art. 192 k.c., sprowadza się do wytworzenia odpadu (np. zniszczenie rzeczy, zdjęcie opakowania z batonika), jak również gdy odpad jest jedynie produktem ubocznym przetworzenia materiału w nowa rzecz (np. ścinki tkaniny powstałe po uszyciu garnituru). W tym ostatnim przypadku odpad dzieli los prawny z „głównym produktem przetworzenia”.

Jak zaznaczono wyżej, bycie właścicielem odpadu nie oznacza bycia podmiotem obowiązków związanych z gospodarowaniem odpadem. Upraszczając, można przyjąć, że najczęściej podmiotem obarczonym tymi obowiązkami od momentu powstania odpadów jest ich pierwotny wytwórca. Ustawa o odpadach w art. 3 ust. 1 pkt 32 definiuje pierwotnego wytwórcę odpadów jako „każdego, którego działalność lub bytowanie powoduje powstawanie odpadów”. Ten sam przepis stanowi, że „wytwórcą odpadów powstających w wyniku świadczenia usług w zakresie budowy, rozbiórki, remontu obiektów, czyszczenia zbiorników lub urządzeń oraz sprzątania, konserwacji i napraw jest podmiot, który świadczy usługę, chyba że umowa o świadczenie usługi stanowi inaczej”.

\section{PIERWOTNE CZY POCHODNE NABYCIE WŁASNOŚCI ODPADÓW?}

Pomiędzy wytworzeniem odpadu a jego docelowym zagospodarowaniem (składowaniem, spaleniem, biodegradacją itd.) może on przechodzić przez ręce kilku podmiotów. Należałoby zatem odpowiedzieć na pytanie, czy procesowi temu towarzyszą utrata i nabycie własności przez podmioty będące kolejnymi ogniwami tego łańcucha.

Interesującym zagadnieniem jest to, jaki charakter prawny ma przejście własności pomiędzy pierwotnym właścicielem odpadu a jego kolejnym właścicielem: Czy dochodzi do pierwotnego nabycia własności, czy tė̇ ma miejsce nabycie pochodne (translatywne)?

Aby rozstrzygnać powyższą wątpliwość, w pierwszej kolejności należy ustalić, czy „pozbycie się” odpadu jest tożsame z „porzuceniem” rzeczy, o którym mowa w art. 180 k.c. („Właściciel może wyzbyć się własności rzeczy ruchomej przez to, że w tym zamiarze rzecz porzuci”).

Wyrażenia „pozbycie się” oraz „porzucenie” nie mają swych definicji legalnych. Przepisy prawa nie precyzują w żaden sposób ich rozumienia. Nie pozostaje zatem nic innego, jak odwołanie się do ich znaczenia w języku naturalnym (potocznym). Jak wspomniano wyżej, według definicji słownikowej „po- 
zbyć się" znaczy tyle, co oddalić, odsunąć coś od siebie, uwolnić się od czegośn ${ }^{23}$. Zgodnie ze słownikowa definicją „porzucić” oznacza: opuszczać, zostawiać coś na łasce losu, rozstawać się z czymśs ${ }^{24}$. Uzasadnione jest zatem stwierdzenie, że czasownik „pozbyć się” jest synonimem czasownika „porzucić”. Z prawnego punktu widzenia oba wyrażenia odnoszone do rzeczy oznaczają wyzbycie się jej posiadania. Zatem pozbycie się rzeczy, o który mowa w art. 3 ust. 1 pkt 6 UO, jest równoznaczne z porzuceniem rzeczy w rozumieniu art. 180 k.c. W konsekwencji należy uznać, że pozbycie się rzeczy, skutkuje nie tylko tym, że rzecz tę należy zakwalifikować jako odpad, lecz ponadto może spowodować wyzbycie się własności odpadu.

Jak wynika z art. 180 k.c., drugim (obok faktycznej czynności porzucenia rzeczy) elementem koniecznym dla zrzeczenia się własności rzeczy ruchomej jest zamiar towarzyszacy jej porzuceniu. Samo wyzbycie się posiadania rzeczy (np. na skutek zdarzeń losowych) bez zamiaru wyzbycia się jej własności nie wywołuje skutków prawnych wskazanych w art. 180 k.c. Aby doszło do utraty własności, oba wskazane elementy muszą wystapić łącznie. Dlatego też zgubienie rzeczy (art. $183 \S 1$ k.c.) lub porzucenie rzeczy bez zamiaru wyzbycia się własności (art. 183 § 2 k.c.) nie wywołuje wspomnianych skutków. Należy zgodzić się przy tym z przeważajaccym $\mathrm{w}$ doktrynie poglądem, że uzewnętrznienie zamiaru wyzbycia się prawa własności jest rodzajem oświadczenia woli (art. 60 k.c.), a samo porzucenie rzeczy jest czynnością prawna jednostronna, realna, o charakterze rozporzacdzajacym ${ }^{25}$. Zamiar wyzbycia się własności może zostać wyraźnie ujawniony przez właściciela bądź wynikać z jego zachowania się w okolicznościach, w jakich rzecz została porzucona, np. przez pozostawienie jej w miejscu przeznaczonym na gromadzenie odpadków ${ }^{26}$.

Pozbywaniu się odpadu w zdecydowanej większości przypadków towarzyszy zamiar zrzeczenia się jego własności. W konsekwencji dochodzi do przekwalifikowania rzeczy porzuconej do kategorii rzeczy niczyich (res nullum) ${ }^{27}$. Wniosek taki jest oczywisty dla sytuacji, gdy pierwotny właściciel odpadu wyrzuca go do kosza na śmieci w miejscu publicznym (papierek wyrzucony do śmietnika w parku), względnie pozbywa się odpadu w miejscu niedozwolonym (butelka pozostawiona w lesie). Dochodzi wówczas do wyzbycia się posiadania w sposób umożliwiający zawładnięcie nią każdemu. Osobie pozbywającej się odpadu jest wszystko jedno, kto ten odpad zbierze. Inaczej mówiąc, dokonując czynności realnej, swym zamiarem obejmuje wyłącznie wyzbycie się prawa własności i nic poza tym.

Nieco mniej oczywistą sytuacja jest ta, w której właściciel nieruchomości gromadzi odpady celem przekazania ich podmiotowi, który zobowiązany jest do ich odbioru. Można wówczas nabrać wątpliwości, czy dochodzi w ta-

23 E. Sobol (red.), op. cit., s. 693.

${ }^{24}$ Ibidem, s. 678.

${ }_{25}$ Tak J. S. Piątowski, w: System prawa cywilnego, t. 3, cz. 2, s. 349; Z. Radwański, w: System prawa prywatnego, t. 2, s. 175 i 182; J. Ignatowicz, K. Stefaniuk, Prawo rzeczowe, Warszawa 2006, s. 112; odmiennie S. Grzybowski w: System prawa cywilnego, t. 1, s. 203-204.

${ }^{26}$ Tak J. S. Piątowski, w: System prawa cywilnego, t. 3, cz. 2, s. 349.

27 Szerzej P. Książek, Rzeczy niczyje, „Rejent” 2005, nr 4, s. 59 i n. 
kim przypadku do zrzeczenia się własności, a następnie objęcia własności rzeczy niczyjej (nabycie pierwotne), czy też mamy do czynienia z przeniesieniem własności rzeczy (nabycie pochodne). Wattpliwość tę należy rozstrzygnąć na korzyść nabycia pierwotnego. Czynnikiem odróżniającym od klasycznej sytuacji regulowanej art. 180 k.c. jest tutaj pozbycie się rzeczy z zamiarem umożliwienia zawładnięcia nią konkretnemu podmiotowi (odbierającemu odpady), a nie komukolwiek. Element ten nie ma jednak znaczenia dla kwalifikacji rodzaju nabycia własności. Przedmiotem stosunku prawnego pomiędzy właścicielem nieruchomości a podmiotem odbierającym odpady jest usługa odbioru odpadu, a nie własność odpadu. Właściciel nieruchomości jest zainteresowany pozbyciem się odpadu i nie obejmuje swym oświadczeniem woli (wyrażonym wprost lub w sposób dorozumiany) przeniesienia własności odpadu. Wniosek ten jest tym bardziej uzasadniony z uwagi na dwie okoliczności:

1. W obecnym stanie prawnym właściciel nieruchomości nie zawiera indywidualnie umowy o wywóz odpadów ${ }^{28}$. Stosunek prawny łączący go z podmiotem odbierającym odpady oraz z gmina, na której rzecz uiszcza stosowna opłatę, ma podstawy ustawowe (UPCG). Przepisy ustawy zaś nie zawieraja postanowień wskazujących na przeniesienie własności odpadów.

2. W praktyce często właściciel nieruchomości nie ma wiedzy na temat tego, czy podmiot odbierajacy odpady zobowiązany jest wyłącznie do transportu odpadów pomiędzy miejscem ich odbioru a miejscem wskazanym przez gminę, czy też jego obowiązkiem jest odbiór i zagospodarowanie odpadów. W takim przypadku właściciel nieruchomości nie mógłby swą świadomościa objąć przeniesienia własności na rzecz konkretnego podmiotu, gdyż nie znałby tego podmiotu. Nie jest zaś możliwe przeniesienie własności na rzecz osoby bliżej nieskonkretyzowanej.

Powyżej zwrócono uwagę, że powstanie odpadu jest immanentnie związane z procesem pozbywania się go. Użycie czasownika w trybie niedokonanym nie jest przypadkowe, gdyż - jak już wspomniano wyżej - dla zakwalifikowania rzeczy jako odpadu wystarczające jest zainicjowanie czynności zmierzających do pozbycia się odpadu (zebranie odpadu). Podobnie jak w przypadku posiadania, również w odniesieniu do prawa własności można wyróżnić okres, w którym rzecz z punktu widzenia prawa jest już odpadem, lecz właścicielem odpadu (pierwotnym) nadal pozostaje osoba pozbywajacca się go. Ostateczne wyzbycie się własności zebranego odpadu następuje dopiero w momencie odbioru tego odpadu przez wyznaczony do tego podmiot.

Fakt ten ma istotne znaczenie $\mathrm{z}$ punktu widzenia oceny prawnej procederu kradzieży odpadów, zwłaszcza tych posegregowanych. Z doniesień mediów wynika, że zdarzenia takie nie są rzadkościa. Zakładając, że odpady stawałyby się rzeczą niczyją już w momencie wrzucenia ich do pojemnika na

\footnotetext{
${ }^{28}$ Nie można tutaj mówić nawet o zawarciu umowy w sposób dorozumiany. Opłata za odbieranie odpadów uiszczana jest na rzecz gminy, a obowiązek jej ponoszenia ma swe źródło bezpośrednio w przepisach UPCG oraz uchwale rady gminy, a nie w jakimkolwiek stosunku umownym. Ponadto ustawodawca wprost stanowi, że umowa na odbieranie odpadów komunalnych od właścicieli nieruchomości jest zawierana pomiędzy gminą a przedsiębiorcą odbierającym odpady komunalne od właścicieli nieruchomości, wybranym w drodze przetargu, o którym mowa w art. 6 d ust. 1 UPCG.
} 
śmieci, czynów tych nie można by zakwalifikować jako kradzieży. Byłoby to legalne nabycie własności ruchomej rzeczy niczyjej przez jej objęcie w posiadanie samoistne (art. 181 k.c.). Co najwyżej można by postawić zarzut naruszenia miru domowego (występek przewidziany w art. 193 k.k.) ${ }^{29}$.

W dużym uproszczeniu, dalsza procedura postępowania z odpadami przebiega, co do zasady, następująco: po zebraniu odpadów komunalnych przez ich pierwotnego właściciela (najczęściej władającego nieruchomością, który zbiera odpady komunalne wytwarzane na terenie tej nieruchomości, bądź wytwórcę odpadów, który wytwarzane przez siebie odpady zbiera w miejscu ich wytworzenia), podlegają one transportowi wykonywanemu przez podmiot zobowiązany do odbierania albo do odbierania i zagospodarowania odpadów ${ }^{30}$. W obu przypadkach transportowane odpady komunalne trafiaja docelowo do miejsca ich przetwarzania (czyli tzw. regionalnych instalacji do przetwarzania odpadów komunalnych - „RIPOK”, względnie tzw. instalacji zastępczych), gdzie podlegają sortowaniu, a następnie odzyskowi (w tym recyklingowi) lub unieszkodliwieniu. Pozostałości po przetworzeniu odpadów winny trafić na składowisko odpadów lub do spalarni.

Analiza wyżej opisanego procesu pod kątem prawa własności odpadów pozwala dojść do następujących wniosków:

1. Podmiot zobowiązany wyłącznie do odbioru i transportu odpadów nie nabywa ich własności. Jego sytuację prawną można przyrównać do sytuacji przewoźnika (dzierżyciela). Osoba ta włada odpadami za podmiot, który zlecił mu ich transport ${ }^{31}$.

2. O własności odpadów komunalnych (nabyciu pierwotnym) można mówić dopiero w przypadku podmiotu odpowiedzialnego za zagospodarowanie odpadów w rozumieniu przepisu 6d ust. 1 UPCG. Nabycie własności odpadów następuje z chwilą ich odebrania od właściciela nieruchomości. Wówczas podmiot odpowiedzialny za zagospodarowanie odpadu przejmuje władztwo nad odpadami bądź bezpośrednio (wówczas gdy jest jednocześnie podmiotem odbierającym odpady), bądź za pośrednictwem podmiotu, który odbiera odpady na jego zlecenie. W drugim z wymienionych przypadków podmiot odbierający odpady (dzierżyciel) obejmuje władztwo nad nimi w imieniu podmiotu odpowiedzialnego za zagospodarowanie odpadów. W obu przypadkach, przejmując władanie nad odpadami, podmiot odpowiedzialny za ich zagospodarowanie staje się ich posiadaczem samoistnym. Nabywa zatem własność odpadów na podstawie art. 181 k.c. (nabycie pierwotne rzeczy niczyjej).

3. W sytuacji gdy podmiot odpowiedzialny za zagospodarowanie odpadu nie jest jednocześnie prowadzącym RIPOK bądź instalację zastępcza, będzie

${ }^{29}$ Zabranie śmieci z prywatnej posesji (w przypadku domu jednorodzinnego czy terenu wspólnoty mieszkaniowej) wiąże się zwykle z „wdarciem” do cudzego pomieszczenia lub na cudzy ogrodzony teren.

${ }^{30}$ Zgodnie z art. 6d ust. 1 UPCG wójt, burmistrz lub prezydent miasta jest obowiązany zorganizować przetarg na odbieranie odpadów komunalnych od właścicieli nieruchomości, albo przetarg na odbieranie i zagospodarowanie tych odpadów.

31 W zależności od tego, czy zorganizowano przetarg na odbieranie odpadów komunalnych od właścicieli nieruchomości, czy przetarg na odbieranie i zagospodarowanie tych odpadów, podmiotem tym jest gmina albo podmiot, któremu gmina powierzyła zagospodarowanie odpadów. 
on musiał zawrzeć umowę $\mathrm{o}^{32}$ zagospodarowanie odpadów komunalnych z podmiotem prowadzacym taką instalację. Na jej podstawie odbierane odpady komunalne winny być przekazywane do wspomnianej RIPOK. Wraz z przekazaniem odpadów następuje wyzbycie się ich posiadania. Należy przyjąć, że ma miejsce przeniesienie własności odpadów pomiędzy stronami umowy o zagospodarowanie odpadów. Prowadzący RIPOK staje się właścicielem przekazanych mu odpadów.

Obowiązująca UO wprowadziła dwa nowe pojęcia, o których warto wspomnieć w kontekście niniejszych rozważań. Mianowicie uregulowała sytuację prawną sprzedawcy odpadów (dealera) oraz pośrednika w obrocie odpadami (brokera). Sprzedawca odpadów został zdefiniowany jako „podmiot, który nabywa, a następnie zbywa odpady, we własnym imieniu, w tym również podmiot, który nie obejmuje odpadów fizycznie w posiadanie" (art. 3 ust. 1 pkt 27 UO). Pośrednik w obrocie odpadami to z kolei według ustawy każdy, „kto organizuje przetwarzanie odpadów w imieniu innych podmiotów, w tym również podmiot, który nie obejmuje odpadów fizycznie w posiadanie" (art. 3 ust. 1 pkt 20 UO). Obie instytucje dotychczas nie funkcjonuja w praktyce, gdyż nie utworzono jeszcze rejestru, do którego wpisowi podlegaliby sprzedawcy i pośrednicy w obrocie odpadami ${ }^{33}$. Zakładając, że wkrótce będzie możliwość prowadzenia działalności przez pośredników w obrocie odpadami oraz sprzedawców, warto przyjrzeć się ich sytuacji prawnej w kontekście prawa własności odpadów, których obrót będzie towarzyszył działalności tych podmiotów.

Z przytoczonych wyżej definicji legalnych wynika, że w toku wykonywania swojej działalności sprzedawca odpadów będzie nabywał i zbywał własność odpadów. Nie stanowi przeszkody w tym zakresie fakt, że sprzedawca może być osoba, która nie obejmuje odpadów fizycznie w posiadanie. Wprawdzie art. $155 \S 2$ k.c. stanowi, że jeżeli przedmiotem umowy zobowiąującej do przeniesienia własności są rzeczy oznaczone tylko co do gatunku (tak należy kwalifikować odpady), do przeniesienia własności potrzebne jest przeniesienie posiadania rzeczy, lecz przeniesienie posiadania rzeczy nie musi polegać na jej faktycznym wydaniu (objęciu w faktyczne posiadanie). Przepis art. 350 k.c. wskazuje przykładowo, że jeżeli rzecz znajduje się w posiadaniu zależnym albo w dzierżeniu osoby trzeciej, przeniesienie posiadania samoistnego następuje przez umowę między stronami i przez zawiadomienie posiadacza zależnego albo dzierżyciela. Oznacza to, że sprzedawca będzie mógł objać posiadanie samoistne odpadów poprzez umowę z poprzednim właścicielem oraz zawiadomienie o tym dzierżyciela (podmiotu odbierającego odpady).

W przypadku brokera nie będzie dochodziło do nabywania własności odpadów. Zadaniem pośrednika w obrocie odpadami jest wyłacznie organizowanie przetwarzania odpadów w imieniu innych podmiotów. Zatem to podmioty, w których imieniu działał będzie broker, nabędą własność odpadów.

${ }^{32}$ Ustawodawca posługuje się sformułowaniem „umowa na zagospodarowanie odpadów” (np. art. 9l, art. 9 za UPCG).

${ }^{33}$ Zgodnie z art. 234 ust. 1 UO rejestr ten tworzy się najpóźniej w terminie 36 miesięcy od dnia wejścia w życie ustawy, tj. najpóźniej do 23 stycznia 2016 r. 


\title{
VII. PODSUMOWANIE. WNIOSKI DE LEGE FERENDA
}

Jak wspomniano wyżej, postanowienia znowelizowanej UPCG nie daja gminie ex lege tytułu własności odpadów komunalnych wytwarzanych na jej obszarze. Choć poczynione wyżej ustalenia na temat reguł przysługiwania oraz przenoszenia prawa własności odpadów dotyczą obecnego stanu prawnego, to można je odnosić również do sytuacji prawnych wyznaczanych poprzednio obowiązującymi normami prawa.

Nałożenie na gminy obowiązku zorganizowania odbierania odpadów komunalnych od właścicieli nieruchomości, na których zamieszkują mieszkańcy, nie ma bezpośrednio wpływu na sferę własności tych odpadów. Zatem popularne $\mathrm{w}$ mediach hasło przejęcia przez gminy własności odpadów komunalnych niewiele ma wspólnego z rzeczywistościa prawna.

$\mathrm{W}$ ramach wniosków de lege ferenda należałoby zgłosić postulat, aby legislatorzy tworzacy projekty aktów normatywnych z dziedziny prawa administracyjnego wykazywali większą precyzję w posługiwaniu się pojęciami, których znaczenie wywiera wpływ w sferze cywilnoprawnej. Nie jest konieczne, aby przepisy UPCG czy UO wprost regulowały zagadnienia ze sfery własności bądź posiadania. Kwestie te moga zostać precyzyjnie ustalone na gruncie interpretacji opartej na ogólnych regułach k.c. Istotne jest jednak, by przepisy wymienionych ustaw nie utrudniały takiej wykładni, wprowadzając zamieszanie terminologiczne. Przykładem krytykowanej tutaj praktyki jest np. tworzenie ustawowej definicji „posiadacza odpadów” (art. 3 ust. 1 pkt 19 UO), która nie pokrywa się z kodeksowym ujęciem instytucji posiadania, oraz używanie pojęcia „władający powierzchnią ziemi”, które nijak ma się do uregulowanych w k.c. tytułów prawnych pozwalajacych na korzystanie z nieruchomości gruntowej.

dr Michat Matuszczak

michal.m@amu.edu.pl

\section{OWNERSHIP OF MUNICIPAL WASTE}

\author{
Sum mary
}

The information disseminated by the media on planned and implemented changes in the waste management system recently gave rise to a widespread thesis that municipalities would take over ownership of municipal waste. This statement, repeated many times, has become imprinted in the public consciousness. It has even entered the language used in law, serving as a kind of mental shortcut. Therefore, it may be worthwhile to analyse on its meaning to determine whether it really reflects current state of affairs. The purpose of this article is to present the conclusions of the legal analysis of the title to waste due to individual legal entities involved in the process of waste management.

At first glance, a reflection on the ownership of municipal waste appears to be void of any significance to the legal or economic extent. However, the conclusions derived from it are not completely free from practical implications, be it, for example, in the event of a theft of waste. At the background of such reflections lies waste management being a real challenge to the modern 
world, and, at the same time, a profitable sector of the economy. There is big money that may be generated from waste removal, management and subsequent recycling. The report prepared by the Bank of America Merrill Lynch in April 2013 'No time to waste - global waste primer' estimates the global market for municipal waste amounting to about 410-430 miliard US dollars, and the broadly understood waste management sector (including radioactive waste, medical waste or garbage incinerators) to one billion US dollars. 
Copyright of Journal of Law, Economics and Sociology is the property of Faculty of Law and Administration of Adam Mickiewicz University in Poznan and its content may not be copied or emailed to multiple sites or posted to a listserv without the copyright holder's express written permission. However, users may print, download, or email articles for individual use.

Właścicielem praw autorskich do „Ruchu Prawniczego, Ekonomicznego i Socjologicznego” jest Wydział Prawa i Administracji Uniwersytetu im. Adama Mickiewicza w Poznaniu. Zawartość czasopisma nie może być kopiowana, przesyłana do innych stron internetowych bądź zamieszczana na blogach bez pisemnej zgody wydawcy. Niemniej artykuły można drukować, kopiować lub przesyłać w formie elektronicznej na własny użytek. 